\title{
Linguistic Deviation in Poetry Translation: An Investigation into the English Renderings of Shamlu's Verse
}

\author{
Hossein Pirnajmuddin \\ English department, University of Isfahan, Iran \\ Email: pirnajmuddin@fgn.ui.ac.ir \\ Vahid Medhat \\ University of Isfahan, Iran \\ Email: vahid.medhat@yahoo.com
}

\begin{abstract}
Poetic diction has its own characteristic features of which anyone who is engaged in the translation of poetry should have a good understanding. Poetry is not merely a matter of rhyme and rhythm. 'Blank verse' is free from such aspects but has still its own poeticality. According to Leech (1969), what makes poetry is the linguistic deviation a poet manipulates in his poetry and therefore linguistic deviation is regarded by him a means of creating artistic beauty. He enumerates eight types of deviations. Since form and content are inseparable in poetry, the translator of poetry should do his best to transfer these two. The translator should also pay attention to linguistic deviations and try to convey them in the translation as far as possible. So far little attention has been paid to linguistic deviations of Persian poetry in connection with translation hence this study tries to investigate this matter by analyzing the deviations in a poem of Shamlu and its English translation rendered by Firuze Papan-Matin. It is shown that though in Shamlu's poetry semantic, historical and lexical deviations are dominant and determining factors of his poetic style, in the translation, it is only semantic deviation which has a high degree of transference and most of the historical and lexical deviations are ignored, resulting in a great loss in the translation concerning the stylistic features of Shamlu's poetry.
\end{abstract}

Index Terms - linguistic deviations, foregrounding, poetry translation, style, Shamlu

\section{INTRODUCTION}

Poetic language, at least in some theorizations, differs from the everyday, ordinary language. In ordinary usage, language is mostly automatic, and words are used in a way that does not attract attention, but in poetry the language is used in such a special way that the reader makes a distinction between poetic language and the daily or usual one. But how is this differentiation made?

Before dealing with this question let us begin with the very notion of language as poetry cannot be imagined outside language. There have been many different definitions for the term. Pei (1966, P. 141) defines language as "a system of communication by sound, operating through the organs of speech and hearing, among members of a given community, and using vocal symbols possessing arbitrary conventional meanings." As Hall (1968, P.18) puts it, "language is the institution whereby humans communicate and interact with each other by means of habitually used oral-arbitrary systems".

What is common in these definitions is that 'language is a means of communication'. However, language is not just a way of communicating daily needs. It also speaks about the cultural loads of centuries, beliefs, traditions and thoughts. To put it in different words, language performs different functions. Jakobson (1981) assumes six basic functions for language: emotive, conative, phatic, metalingual, referential and poetic. Among these functions, poetic function is related to the aesthetic and artistic aspects of language and is mainly used in literature and poetry.

Although Jacobson does not reduce the domain of poetic function to poetry, he considers it to be the dominant and determining function of verbal art, whereas in all other verbal activities "... it acts as a subsidiary, accessory constituent" (p. 25). Halliday uses the term 'textual function' and Martinet 'aesthetic function' to refer to this function of language (Halliday and Hassan, 1985). Literary language and poetry as a part of it use this function to a great extent whereby making the language more beautiful.

In principle, the language of poetry comes into existence when some norms are broken or deviated from. According to Shafii-Kadkani (1989), "poetry is nothing but breaking the norms of ordinary and logical language" (p. 240). Shamisa (2004) also believes that there is almost no literary work that does not involve a sort of deviation from ordinary language and assumes that the subject of linguistic deviation should not be neglected because in some cases all of the importance and influence of a literary work depends on it (p. 158). 
Russian formalists considered literature as a special use of language which achieves its distinctness by deviating from and distorting practical language (in Selden, Widdowson, Brooker, 1997, p. 32). The proper study of literature, they declared, is literature itself. To Study literature, they asserted, is to study 'poetics', which is "an analysis of a work's constituent parts- its linguistic and structural features- or its 'form' " (in Bresseler, 2007, p. 51). As they argued, form includes what they call 'devices' which comprise the artfulness and literariness of any text.

The formalists' chief focus of literary analysis was the examination of a text's 'literariness', the language used in the text. They believed that literary language is different from everyday language. Unlike ordinary speech, literary language foregrounds itself. Through devices such as imagery, structure, paradox, rhyme scheme etc, literary language identifies itself as deviations from everyday speech patterns and produces the defining feature of literariness, i.e. 'defamiliarization'. Introduced by the Russian formalist Victor Shoklovsky, defamiliarization is the process of making strange the familiar: "art exists in order to recover for us the sensation of life which is diminished in the automatized routine of every day experience" (in Baldick, 2004, p. 62). The result of this process of defamiliarization is that it enables us once again to see the world anew, in its all splendor.

Mukarovsky (1932), a member of Prague Linguistic Circle, developed the formalist concept of 'defamiliarization' into the more systematic 'foregrounding' which he defined as 'the aesthetically intentional distortion of the linguistic components' (in Selden, Widdowson, Brooker, 1997, p. 38). Foregrounding causes the reader "to draw attention from the putative paraphrasal meaning of a message "what is said' to focus on the message itself "how it is said"" (Fowler, 1987, p. 98).

Leech (1969) has applied the concept of foregrounding to poetry. He considers the foregrounded figure as 'linguistic deviation', while the background is the language itself (p. 57). According to Leech, It is a very general principle of artistic communication that "a work of art in some way deviates from norms which we, as members of society, have learnt to expect in the medium used" (1969, p. 56). In a work of art, as he argues, the artistic deviation 'sticks out' from its background, the automatic system, like a figure in the foreground of a visual field. In case of poetry, "the foregrounded figure is the linguistic deviation, and the background is the language - the system taken for granted in any talk of deviation" (p. 57).

Leech (1969) believes that, what makes poetry is the linguistic deviations the poet manipulates in his poetry and therefore linguistic deviation is regarded by him a means for poetic creation. For him, a linguistic deviation is artistically significant when a. it communicates something, b. it communicates what was intended by its author and c. it is judged or felt by the reader to be significant (p. 59). He introduces eight types of linguistic deviation in poetry which are as follows:

1. Lexical deviation, 2. Grammatical deviation, 3. Phonological deviation, 4. Graphological deviation, 5. Semantic deviation, 6. Dialectical deviation, 7. Deviation of register, and 8. Deviation of historical period.

In Shamlu's poetry, which is the focus of this study, deviations play an important part. In other words, the significance of Shamlu's poetry is his artistic use of language that is to a great extent achieved through linguistic deviations. For example, consider this line from Shamlu:

$$
\text { ما بى جر ا زندكانيم آنان به جر ا مرك خويش آخاهانند }
$$

(We are the reasonless-living. They are of their death-reason aware.)

And its putative paraphrasal meaning:

ما نميدانيم جر ازنده ايم اما آنها ميدانند جر ا ميميرند

(We don't know why we are alive. They know why they are dying.)

We count the first sentence as a piece of poetry while we do not feel any poetic element to be in the second one. In fact, the poeticality of the first line is due to the linguistic deviations Shamlu has manipulated in the sentence.

How to translate these deviations and if they are translatable, is the challenging issue presented to the translator. The translator must be able to recognize these deviations and also be sufficiently skilful in conveying them in the translation.

As a matter of fact, translation of poetry as the most intense form of literature has always been a matter of debate. It is a generally accepted view that the translation of poetry is the most difficult, challenging and possibly rewarding form of translation. This famous saying by Robert Frost "Poetry is what is lost in translation" is often quoted in literature to highlight the difficulty of the task (in Baker, 1998, p. 170). Jakobson (1959) holds that "Everything is translatable except poetry because it is the very form, the very phonetic quality of a poem in a language which makes a poem" (in Lodge, 1998, p. 18).

Since the style of poetry is more imaginative, concentrated, complex, and powerful than that of ordinary prose, it is very difficult, sometimes impossible, to transfer all the linguistic features of a poem from one language into another. Nevertheless, it is necessary for the translator of poetry to pay a close attention to the style matters, for style marks the authorship of a poem and also distinguishes poetry translation from other kinds of translations.

To find the style of a certain poem, the instances of linguistic deviation should be investigated. Afterwards, the translator should try his best to reproduce these qualities so that the same effect and impression could be reproduced for the target reader.

This study will, therefore, aim at comparing the linguistic deviations of one of Shamlu's poems with its English translation by Firuze Papan Matin to see whether the translator has been aware of such deviations and what has happened to them in the process of translation. 


\section{TYPES OF DEVIATIONS}

In what follows a brief survey of the classification of linguistic deviations, as introduced by Leech, has been presented. The English examples are from Leech (1969).

\section{A. Lexical Deviation}

There is lexical deviation when the poet invents new words. Neologisms are examples of this. Here, however, the term neologism is not limited to coinage of words. It includes, in a broad sense, novelty in using words. Therefore, some compounds which represent a type of innovation can also be regarded as instances of lexical deviation:

The widow-making unchilding unfathering deeps. (Hopkins)

By inventing new words and combinations, a poet may help expanding and developing the language- something probably seen in Shamlu's poetry. In fact, using different kinds of combinations is the characteristic feature of Shamlu's poetry. Although some of these combinations have already been used by others, a great number of them have been tapped for the first time by Shamlu himself.

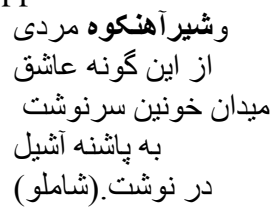

\section{B. Grammatical Deviation}

It is a kind of deviation in which the poet disregards the rules of sentence or syntactic features:

Our heart's charity's health's fire, .... . (Hopkins)

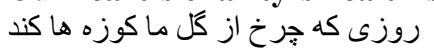

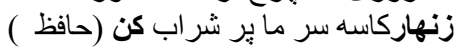

\section{Phonological Deviation}

This is the deviation in sound or pronunciation which is done deliberately in regard to preserving the rhyme, as when the noun wind is pronounced like the verb wind.

Leech considers the phonological deviation as "irregularities of pronunciation":

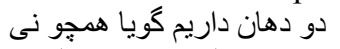

$$
\text { يك دهان بنهانست در لبهاى دوى (مولوىى) }
$$

\section{Graphological Deviation}

This is a type of deviation that is related to the poet's disregard of the rules of writing. It is the line-by-line arrangement of the poem on the page with irregular margins. The graphological deviation or the special way of putting words and lines on the page may add a sort of second meaning to the original meaning of the verse:

seeker of truth

follow no path

all paths lead where

truth is here (Cummings)

با خويشتن، نشستن

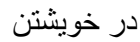

ش خو

$\checkmark$

w

$ت$

$$
\text { ن }
$$

\section{E. Semantic Deviation}

It is a sort of deviation related to the irrational element of meaning in poetry. It leads the mind to comprehension on a figurative plane. Concerning semantic deviation, Leech believes that in all great poetry this irrational element is present. He considers it so important an element of poetic language that "poets and critics alike have tended to consider it the only thing that really matters in poetry" $(1969$, p. 49).

While encountering semantic deviation, the figurative meaning becomes necessary because the literal meaning gets absurd. In other words, semantic deviation occurs when the literal interpretation of a sentence or a line of poetry is nonsensical, and there remains no choice but figurative interpretation of the sentence:

The child is father of the man. (Wordsworth's)

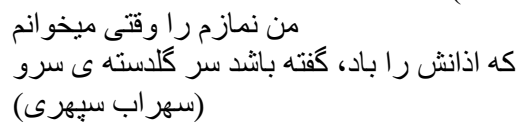




\section{F. Dialectal Deviation}

Dialectal deviation, or to use Leech's term 'dialectism', refers to the borrowing of features of socially or regionally defined dialects. It occurs when the poet enters into his poetry words or structures which are from a dialect different from that of standard language; using words like heydeguyes (a type of dance), rontes (young bullocks), wimble (nimble),... by Spenser is of this type of deviation.

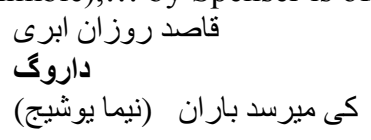

\section{G. Deviation of Register}

In poetry, it refers to borrowing language from other non-poetic registers or using the features of different registers in the same text:

And many a bandit, not so gently born

Kills vermin every winter with the Quorn. (Auden)

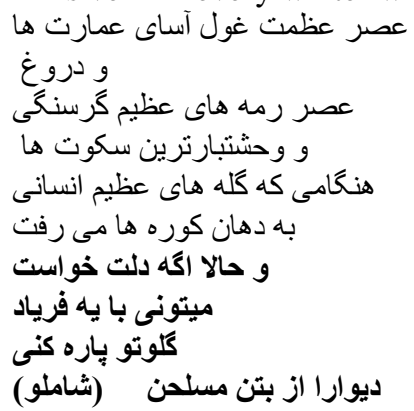

\section{H. Deviation of Historical Period}

In this kind of deviation the poet uses archaic words or structures which are no longer used in standard language to enhance the aesthetic or musical value of the poem. Leech calls historical deviation 'archaism' and defines it as "the survival of the past into the language of present time" (1969, p, 52):

The association of man and woman

In daunsinge, signifying matrimonie-

A dignified and commodious sacrament,

Two and two, necessarye coniunction,

Holding eche other by the hand or the arm

Which betokeneth concorde. (T.S. Eliot)

غبار آلوده، از جهان

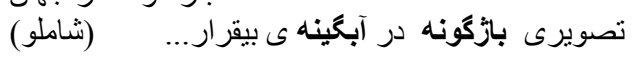

\section{METHODOLOGY}

\section{A. Materials and Procedure}

The main approach adopted in this research is the one proposed by Leech (1969). Leech believes that what creates poetry is the linguistic deviation the poet manipulates in his poetry and, therefore, linguistic deviation is regarded by him as a means for creating poetry. But deviations are subject to some restrictions. Not all kind of deviation from the norms of standard language, as Leech asserts, is a means of creating artistic beauty. He introduces eight types of linguistic deviations: lexical, phonological, semantic, dialectal, syntactic, graphological, deviation of historical period, and deviation of register types.

The materials for this research include a poem of Shamlu entitled 'nocturnal/shabane' and its English translation by Firuze Papan-Matin (2005). In the light of the classification of linguistic deviations made by Leech (1969), the present study aims at analyzing the linguistic deviations in this poem via comparing it with the English translation to see to what extent these deviations are translatable and what has happened to them in the process of translation.

To do so, the instances of linguistic deviations in Shamlu's poem are specified and compared with the translation. Some types of linguistic deviations introduced by Leech are not present in this poem because they are not dominant in Shamlu's poetry; however, this study tries to analyze all linguistic deviations present in the poem to answer these questions:

1. Which types of linguistic deviations presented by Leech are dominant in this poem of Shamlu?

2. To what extent has the English translation been successful in conveying the linguistic deviations of the poem?

\section{B. Ahmad Shamlu and Blank Verse}

For some people when the norm of standard language is changed by rhyme and meter, the language turns into poetry. But Poetry cannot be reduced to rhyme and meter. Free verse is a kind of poetry in which meter does not follow a clear 
pattern, and the length of lines is irregular and ever-changing. 'Vers blanc' or 'blank verse' is also a kind of verse that can be free from both meter and rhyme at the same time as it bears an unanticipated music of its own. The music in blank verse is an "offspring of the constitutive elements of the individual poem and does not abide by stylistic rules imposed on the poem from without" (Papan-Matin, 2005, p. 27).

Ahmad Shamlu is one of the most celebrated figures of contemporary Iranian poetry. His poetry, which is the focus of this study, is characterized by the special use of language which results in poeticality of his poetry. Shamlu found it necessary to set poetry free from the traditional ties of prosodic meter and introduced his own style of poetry as 'vers blanc' and accordingly a new period in Persian poetry came into existence. As Shamlu himself asserts, "I regard rhythm as an external and imposing element: something causing deviation of poet's mind and hindering natural creation of a poem" (in Hariri, 1993, p. 50).

He substituted prosodic regularities with 'internal music' and paid attention to the 'change in the inner structure of the poem' which, as Mojabi (1998) observes, "is based on understanding the music and harmony of words and artistically handling the language that culminates in the achieved composition of the poem" (p. 74). According to Hoghughi, "the music in Shamlu's poetry is not based upon any regular pattern, but something which is achieved as a result of his selection of musical and ear-pleasing words and his mastery in placing such words near each other" (1997, p. 14).

Shamlu believed that a poem reflects a specific instance of experience that brings with it its own musical expressions. He (in Hariri, 1993, p. 89) describes this poetry as an event, an intense instance of illumination with a life of its own. For him, writing poetry is not a conscious, deliberate activity but, the poem's sounds, words, and voices are not revealed to him until the instant when the poem halts him in order to disclose itself to him.

\section{DATA ANALYSIS}

The poem and instances of linguistic deviations:

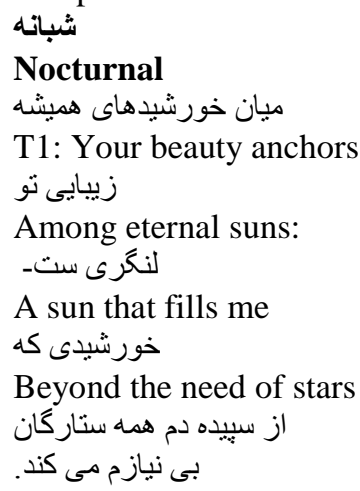

In the first three lines of the original poem there are two similes: likening of beauty to the sun, and beauty to anchor. They can be regarded as instances of semantic deviations. In the translation, one of these similes is not present; and for the other one the translator has employed a metaphor in her translation as 'your beauty anchors me' which is an instance of semantic deviation.

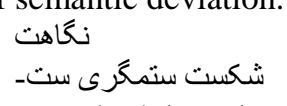

Your look is a victory ongoing

نحاهى كه عريانى روح مرا

Over heartlessness

از مهر

The look that clothed with love

جامه اي كرد

My naked soul

Here, again, there are two instances of semantic deviation: the metaphor in the first sentence 'negahat shekast setamgarist'; and the personification in 'oryanie ruh'. These deviations are successfully transferred in the translation as 'your look is a victory ongoing' and 'naked soul' respectively. But the historical deviation in the words 'jame' and 'oryan' is neglected in the translation.

بدان سان كه كنونم

So that now

شب بى روزن هركز

Night without a flicker of hope

جنان نمايد كه كنايتى طنز آلود بوده است.

Seems ironic, a fanciful joke

Here the phrase 'shabe birozane hargez' represents a special way of using language because of its brevity and precision; it can be regarded as a sort of grammatical deviation as the arrangement of the parts of the sentence is 
different from the normal arrangement of the parts of a sentence in the standard language. This sort of deviation is, however, neglected in the translation in spite of the fact that the translation is semantically correct; this phrase is translated as 'night without a flicker of hope'. Also, using the words 'bedansan' and 'kenayat' and 'konunam' indicates deviations of historical period which is a kind of deviation not present in the translation. Again 'tanzalud' represents a sort of lexical deviation which is translated as 'fanciful'.

و جشمانت با من كفنتند

And your eyes convinced me

كه فردا

That tomorrow will be born again

روز ديكرى ست-

There is a metaphor (personification) or semantic deviation in the first line as 'eye' cannot 'say' anything to anybody; it is rendered as 'your eyes conceived me' which does not include the semantic deviation of the original poem because the verb 'goftan/ to say' is translated as 'to convince'. Also the special use of the preposition 'ba' instead of 'be' is a case of archaism which is not conveyed.

آنك جشمانى كه خمير مايه ى مهر است!

Your eyes the essence of love:

وينك مهر تو:

That love itself is the armoury

نبرد افزارى

That fits me to grip, to greet, my destiny.

تابا تقدير خويش يُنجه در ينجه كنم.

The words 'anak' and 'inak' are instances of historical deviation. These deviations are not transferred. The compounds 'khamirmaye' and 'nabardafzar' are instances of lexical deviations, though not neologisms, but in the translation they are not conveyed as compound and are translated as 'essence of love' and 'armoury' respectively.

آفتاب را در فر اسو هاى افق بنداشته بودم.

I had conceived the sun far beyond the horizon.

به جز عزيمت نابهنگامم كزيرى نبود

No escape but my precocious will-

جنين انحاثته بودم.

I imagined it so.

آيدا فسخ عزيمت جاودانه بود.

Ayda: the dissolution of that eternal will

Here, 'pendashtan', 'engashtan' and 'azimat' are historical deviations; these deviations are not present in the translation. There is also a notorious case of mistranslation: the word 'azimat', which has the meaning of 'to go somewhere', is translated as 'will' which is completely different in meaning.

ميان آفتابهاى هميشّا

Your beauty anchors me

زيبايیى نو

Among eternal suns

لنكرى ست-

نكاهت

شكست ستمكرى ست-

Your look victorious

و جشمانت با من كفنتد

And your eyes

كه فردا

Conceived me

روز ديكرى ست.

That tomorrow will be born again.

Though Shamlu's poetry as blank verse is not restricted by the mandate of rhyme and rhythm, in some cases he uses words which rhyme, and this can somehow improve the efficacy of his expression. Here the words 'digar', 'setamgar' and 'langar' rhyme; however, the translation has failed to transfer these musical elements. Again, there are some repeated instances of semantic deviations in these lines (already discussed).

\section{DISCUSSION AND CONCLUDING REMARKS}

Safavi (2004) in his book From Linguistics to Literature: poetry ( $2^{\text {nd }}$ volume) reexamines the subject of linguistic deviation as introduced by Leech and provides some Persian examples for each kind of deviations. After detailed discussion of the issue of deviation in Persian poetry, he concludes that among these eight types of linguistic deviation only five of them can be regarded as tools for creating artistic beauty, which are historical, graphological, lexical, register and especially semantic deviations. As he argues, phonological, and grammatical deviation are used as a means 
of preserving rhythm and cannot be regarded as tools for creating poetry; and in the case of dialectal deviation, though it can be effective for recognizing the style of a poet, it cannot be counted as an instance of irregularity or deviation, because using borrowed words is also common in the standard language and cannot be regarded as a tool for creating poetry.

As he argues, all kinds of deviations are made as a result of a 'selection' on the paradigmatic axis of language so that on the syntagmatic axis they are not compatible with the existing rules of automatic language. What creates poetry, he (2004, p. 169) continues, are the kinds of deviations which make the 'senses/مدلول' more distant from the 'مصداق/referents', and that is why they are reality-elusive. Among the kinds of deviations, he asserts, semantic deviation makes the greatest distance between sense and referent and can include numerous devices which are classifiable (for example, simile or metaphor) on the basis of their function on the syntagmatic and paradigmatic poles.

Safavi, then, makes a classification of these five poetic elements on the basis of their frequency. As mentioned before, Safavi believes that distancing sense from its referent of outside world creates imaginary speech, that is, a speech which is naturally reality-elusive. So, in terms of the distance created between sense and referent, he specifies the frequency of each deviation theoretically. Safavi provides the following graph for deviations in terms of their frequency:

Semantic deviation > lexical deviation > historical deviation > register deviation > graphological deviation

In this graph, each deviation is less creative in comparison to the deviation placed on the left. In other words, each deviation, in comparison to the left deviation, makes the sense less distant from the referent. For example, lexical deviation is more involved in making the speech imaginary than historical deviation and less involved than semantic deviation. Nevertheless, Safavi acknowledges that this sketch is still too theoretical and a comprehensive research is needed to substantiate it.

As regards this study, and to answer the first research question, investigation showed that semantic, historical and lexical deviations are dominant in this poem of Shamlu. In the original poem, there were 9 instances of semantic deviation, 3 examples of lexical deviation and 12 cases of historical deviation.

There was also found one case of grammatical deviation. As for the other types of linguistic deviation, no instance was found; that is to say, this poem does not include any case of phonological, dialectal and register deviation. Concerning graphological deviation, again, this poem does not have any special instance like what we saw in the example of 'shekastan' cited before in the discussion of types of deviations. However, the verse lineation and punctuation of the poem may cause deliberate pauses or stresses on some words or lines that this may help reading the poem in the way Shamlu has intended.

The scarce instances of phonological, grammatical and dialectal deviations in this poem support Safavi's opinions about deviations. In his account, grammatical, dialectal and phonological deviations do not essentially create poetry as they are mainly used to preserve meter or to show the belonging of a poem to a special geographical place. Moreover, they are of too low a frequency to be considered as a means of poetic creation. Concerning graphological deviation and deviation of register, though the special kind of verse lineation in Shamlu's poetry helps reading his poem in a more special way and mingling poetic register with colloquial one is seen in some of his poems, they are not of too high a frequency to be considered dominant factors of his poetry.

Since style is a very important issue in poetry, it is necessary for the translator of poetry to pay a close attention to the stylistic features. The translator's awareness of the source language stylistic features and techniques affects the quality of the final translation considerably.

As presented above, in Shamlu's poetry semantic, historical and lexical deviations were dominant and determining factors of his poetic style. However, as to the second research question that was earlier posed, in the translation it was only semantic deviation which had a high degree of transference; and historical and lexical deviations were mainly ignored.

In poetry, both form and content are important. To look at deviations from a different angle, one can say that semantic deviation is related to the content of poetry and the other kinds of deviations are more or less connected to the formal aspects of it. As the translator was successful in transferring the majority of the instances of semantic deviations, one can say that the content of the original poem has mainly been conveyed. This is the admirable point about the translation, because as argued before, semantic deviation is the most important type of deviation. However, since in this translation the other types of deviations, especially historical and lexical ones as dominant factors of Shamlu's poetry were not mainly transferred, one can say that the formal features of the original poem have not been conveyed to an acceptable degree. The translator's failure in transferring lexical and historical deviations is the weak point of the translation.

The importance of Shamlu's poetry is not only in the images and concepts he presents, but also in the language he uses- contrary to the poetry of, for example, Forugh Farrokhzad or Sohrab Sepehri which is not so language-dependent. In Shamlu's poetry there are a lot of instances of lexical deviations, the words and combinations he has created for the first time. Again, in his poetry, archaism is the characteristic feature. According to Shafii Kadkani (1989), "in Shamlu's successful works the consideration of archaism is one of the most important elements of linguistic distinctness that can to some extent compensate for the lack of rhythm in his poetry" (p. 25, my translation). It gives his poetry a sort of epic 
coloring and also a flavor of the past. However, as the findings of the study showed there are a lot of losses in the translation concerning the stylistic features of his poetry.

Based on what was said, the reasonable conclusion to arrive at may be that a literal method of translation is generally useful in the case of linguistic deviations because exclusion or omission of these poetic devices may have drastic effects on the style of the text. For example, in the case of historical and lexical deviations, the translator should try his/her best to create new words and compounds (just like that of original poems), and also make use of archaic words and combinations accessible in English. However, the translator should be careful so that creating new combinations and using archaism may not mar the unity or naturalness of the translation.

Finally, it could be concluded that Shamlu's poetry is, in all, more difficult to translate than the poetry of, say, Sohrab Sepehri because, as mentioned before, it is very language-dependent. The comparatively few translations of Shamlu's poetry probably has something to do with this.

\section{REFERENCES}

[1] Baker, M. (1998). Encyclopedia of Translation Studies. London and New York: Rout ledge.

[2] Baldick, C. (2004). Concise Dictionary of Literary Terms. New York: Oxford University Press.

[3] Bressler, C, E. (2007). Literary Criticism. $4^{\text {th }}$ edition. New Jersey: Prentice Hall.

[4] Fowler, R. (1987). A Dictionary of Modern Critical Terms. London: Routledge \& Kegan Paul.

[5] Hall, R. A. (1968). An Essay on Language. New York: Chilton Books.

[6] Halliday, M. A. K and Hasan, R. (1985). Language Context and Text: Aspects of Language in a Social Semiotic Perspective. Victoria: Deakin university press.

[7] Hariri, N. (1993). Gofto shonudi ba Ahmad Shamlu. An Interview with Shamlu. (3 $3^{\text {rd }}$ edition): Avishan.

[8] Hoghughi, M. (1997). Shere zamane ma, Ahmad Shamlu. The Poetry of our Time, Ahmad Shamlu. $4^{\text {th }}$ edition: Negah.

[9] Jakobson, R. (1981). Linguistic and Poetics. In Newton K. M. Twentieth Century Literary Theory. London: Macmillan.

[10] Leech, G. (1969). A Linguistic Guide to English Poetry. London: Longmans.

[11] Lodge, D. (1988). Modern Criticism and Theory. New York: longman.

[12] Mojabi, j. (1998). Shenakhtname Ahmad Shamlu. Get to Know Ahmad Shamlu. Ghatre.

[13] Papan-Matin, F. (2005). The Love Poems of Ahmad Shamlu. Bethesda, Maryland: IBEX publishers.

[14] Pei, M. (1966). How to Learn Languages and What Languages to Learn. New York: Harper \& Row Publishers.

[15] Safavi, K.(2004). Az zabanshenasi be adabiat (jelde dovvom: sher). From Linguistics to Literature ( $2^{\text {nd }}$ volume: Poetry). Tehran: Sureye Mehr.

[16] Selden, R. Widdowson, P. and Brooker, P. (1997). A Reader's Guide to Contemporary Literary Theory. London: Prentice hall.

[17] Shafii Kadkani, M. (1989). Musighie sher. Music of Poetry. $2^{\text {nd }}$ edition (extended and revised text). Tehran: Agah publications.

[18] Shamisa, C.(2004). Naghde adabi. Literary Criticism. Tehran: Mitra.

[19] Shamlu, A. (2008). Majmue asare ahmad Shamlu, daftare yekom: sherha. The Collection of Shamlu's Works, First Book: poetry. Tehran: Negah.

Hossein Pirnajmuddin, born in 1972 in Isfahan. BA in English from Shahid Bahonar University of Kerman 1994. MA in English literature from University of Tehran 1996. PhD in English literature from University of Birmingham 2002. Teaching at Kashan University 2002-2004. Assistant professor in English literature since 2004 at University of Isfahan. Field of interest: modern literary theory, colonial and postcolonial studies, Renaissance studies and translation studies.

Vahid Medhat, born in Estahban, Iran. BA in English translation from Shahid Bahonar University of Kerman 2007. MA student of English translation at University of Isfahan, Iran. Vahid's interest in the English language stems from the time when beginning formal study of the English language as a student in Shahid Bahonar University. As a part of the undergraduate degree, Vahid focused on literary translation criticism of Persian poetry and went on to make modern Persian poetry the focus of master's degree. 